\title{
A construção do conceito de feminilidade na obra freudiana
}

\author{
The development of feminility as a concept in freud's work
}

Fernanda Cabral Samico.

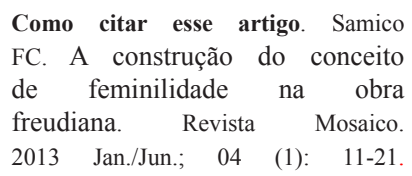

\section{As primeiras incursões teóricas acerca da sexualidade feminina: 1905 a 1920}

Em 1905, no impactante texto Três Ensaios sobre a teoria da sexualidade, Freud lança a premissa psicanalítica de que a sexualidade e seus arranjos estão além das configurações anatômicas dos corpos, ou seja, a realidade do sexo não é a do órgão anatômico. Não há, portanto, entre os seres falantes, harmonia entre o sexual e a reprodução, ou seja, a genitalidade. Isto se desdobra na escolha de objeto, que também não é definida a priori, como nos animais. Há, portanto uma separação entre o desejo sexual e seu objetivo "natural" de reprodução. Uma vez que não está a serviço da reprodução, a sexualidade dos seres humanos tem como principal característica a obtenção de prazer, não apenas genital, mas circunscrevendo todo o corpo, ideia que Freud utiliza como argumentação no estudo das perversões, que toma todo o primeiro ensaio.
O que marcaria, portanto, a singularidade da sexualidade humana é a transitoriedade do objeto que é eleito para a satisfação sexual, o que afasta totalmente o humano do movimento sexual instintivo presente nos outros animais. O ser humano se afasta do movimento cíclico da natureza ao submeter-se ao campo da linguagem.

No segundo ensaio, mais especificamente, Freud se debruça no estudo da sexualidade infantil, suas manifestações e conseqüências. No que diz respeito à investigação sexual infantil, Freud afirma que o único órgão sexual que é reconhecido ou representado no psiquismo e no inconsciente é o pênis. "A suposição de uma genitália idêntica (masculina) em todos os seres humanos é a primeira das notáveis e momentosas teorias sexuais infantis." (FREUD, [1905]1996, vol. VII, p. 184) A primeira das teorias sexuais infantis consiste, então, em atribuir a todos a posse de um pênis, inclusive às mulheres. Isto implica que, tanto para o 
homem quanto para a mulher haveria somente uma representação sexual: a masculina. $\mathrm{O}$ que é feminino resta sem definição.

Este argumento também se encontra no texto Sobre as teorias sexuais das crianças, de 1908, onde Freud afirma ser uma característica infantil "atribuir a todos, inclusive às mulheres, a posse de um pênis ${ }^{1}$." (FREUD, [1908]1996, vol. IX, p. 196) Os meninos falseariam sua percepção ao se depararem com o corpo nu de uma menina e creditariam a ausência de um pênis ao fato de que o mesmo ainda não crescera. Em sua Análise de uma fobia em um menino de cinco anos (1909), esta teoria infantil é deveras exemplificada nas falas do pequeno Hans, comunicadas a Freud pelo pai do menino. Hans utiliza a lógica de que a mãe possui um "faz-pipi" (Wiwimacher) e que sua irmãzinha recémnascida possuiria um também, que cresceria junto com ela.

As meninas, por outro lado, desenvolveriam um interesse pela parte do corpo masculino que não possuem, seguido de um sentimento de inveja, pois se sentiriam prejudicadas por o não possuírem. A consequência freudiana para esta falta de representação para a sexualidade feminina seria a Penisneid, a inveja do pênis. As mulheres estariam condenadas ao sentimento de inveja feminino, vivido a partir do reconhecimento da falta do órgão.

Frente ao reconhecimento da diferença anatômica entre os sexos, André nos ensina que há uma "clivagem entre o psíquico e o anatômico: perceptível ao nível da anatomia, a diferença não se inscreve como tal no psíquico." (ANDRÉ, 1998, p. 170). Essa clivagem posiciona as atitudes de meninos e meninas no que diz respeito a uma maneira de pensar a diferença: do lado do menino, o medo da castração e do lado da menina, a inveja do pênis. É a primeira indicação da universalidade do pênis como teoria da diferenciação dos sexos.

Outro ponto importante que o texto de 1905 apresenta é a teoria da libido. No que toca à teorização da libido, esta também é apresentada como de natureza masculina, seja ela, atuante no homem, ou na mulher. Assim como teorizado anteriormente, masculino e feminino possuem os correlatos atividade e passividade, respectivamente. Toda teoria da sexualidade, portanto, no que diz respeito à construção da masculinidade e da feminilidade será, neste período da doutrina psicanalítica, subordinada à noção de atividade e passividade. Encontramos um bom exemplo no texto Fantasias histéricas e sua relação com a bissexualidade (1908), onde Freud ensina que: "Os sintomas histéricos são a expressão, por um lado, de uma fantasia sexual inconsciente masculina e, por outro lado, de uma feminina."(FREUD, [1908]1996, vol. IX, p. 153).

Uma vez que a masculinidade implica atividade e a feminilidade, por sua vez, passividade, Freud

1 Grifos do próprio autor define o tornar-se homem pelo vetor ativo da virilidade peniana, porém a questão da feminilidade permanece como problema a ser elucidado. Neste momento da obra freudiana, o sexo feminino e a feminilidade estão referenciados à masculinidade. Quando se refere ao desenvolvimento sexual das meninas, Freud afirma:

Quando se quer compreender a transformação da menina
em mulher, é preciso acompanhar as vicissitudes posteriores
dessa excitabilidade do clitóris. A puberdade, que no
menino traz um avanço tão grande da libido, distingue-
se na menina, por uma nova onda de recalcamento, que
afeta justamente a sexualidade do clitóris. O que assim
sucumbe ao recalcamento é uma parcela da sexualidade
masculina. (FREUD, [1908]1996, vol. VII, p. 208-209)

Freud sustenta, então, que há um tempo anterior no desenvolvimento sexual das meninas, cuja atividade é tipicamente masculina e o órgão sexual principal é o clitóris, correlato da zona genital masculina, a glande. Em conformidade com esse fato, haveria uma sexualidade primitiva das jovens, de caráter inteiramente masculino e uma onda de repressão desta masculinidade na puberdade é exigida antes que o clitóris ceda lugar à vagina e a masculinidade, à feminilidade. Essa noção de um tempo masculino anterior à passagem para a feminilidade é o embrião da teorização de uma fase préedipiana, marcada por uma passagem da sexualidade ativa para uma passiva, juntamente com a troca de objeto de amor, como veremos mais adiante.

A teorização acerca da transformação da menina em mulher se daria, então, pela passagem da atividade para a passividade. Freud desenvolve esta teoria posteriormente, quando se debruça exclusivamente sobre a questão da sexualidade feminina.

\section{As teorias sobre a feminilidade entre 1911 e 1920}

Partindo da idéia da universalidade do pênis desenvolvida nos anos de 1905 e 1908, Freud constrói uma teoria da sexualidade feminina tomando como reflexo, ou imagem, a sexualidade masculina. Sobre isto ele é claro quando afirma na Conferência XXI, de 1916, ao tratar do complexo de Édipo:

Como veem, descrevi-lhes apenas a relação de um menino para com seu pai e sua mãe. As coisas se passam de modo exatamente igual com as meninas, com as devidas modificações:umaafetuosaligaçãocomopai,umanecessidade de eliminar a mãe, por julgá-la supérflua, e de tomar-lhe o lugar, um coquetismo que já utiliza os métodos da futura feminilidade (...) (FREUD, [1916]1996, vol. XVI, p. 337)

Nesse momento da doutrina psicanalítica o desenvolvimento libidinal das meninas é idêntico ao dos meninos e a marca do que é tipicamente feminino está sob a lei da passividade. É importante notarmos, 
por outro lado, que Freud aponta que o coquetismo seria um artifício da futura feminilidade, apontandonos uma identificação com a figura feminina que a mãe encarnaria. A mãe, portanto, ao adotar o papel da mulher desejada pelo pai, tornar-se-ia modelo para a menina e ocuparia um lugar no acesso da filha à feminilidade.

Alguns anos antes, mais precisamente em 1911, Freud escreve o texto Formulações sobre os dois princípios do acontecer psíquico onde fundamenta a distinção dos dois princípios reguladores dos processos psíquicos, a saber, o princípio do prazer e do princípio da realidade. É neste pequeno artigo que se encontram as bases para argumentações teóricas que culminariam no texto sobre o Narcisismo, de 1914. Neste texto Freud defende a existência de um narcisismo normal e primário, uma vez que “(...) originalmente o Eu é investido de libido e (...) uma parte dessa libido é depois repassada aos objetos; contudo, essencialmente, a libido permanece retida no Eu." (FREUD, [1914] 2004, vol. I, p. 99) Também existe o movimento antitético entre libido do Eu e libido do Objeto. Quanto mais uma é empregada, mais a outra se esvazia. O exemplo de uma pessoa apaixonada é indicado para o entendimento do esvaziamento da libido do $\mathrm{Eu}$ em favor da libido objetal. Freud escreve sobre o enamoramento, alguns anos depois, em seu trabalho Psicologia de grupo e análise do ego (1921). Nele, Freud aplica o entendimento do investimento libidinal narcísico na análise do enamoramento e do mecanismo da hipnose. Em ambos há uma supervalorização do Outro e não do $\mathrm{Eu}$, a ponto de haver um movimento de investimento de libido do $\mathrm{Eu}$ no Objeto, destituindo o Eu de sua catexia. Nas palavras de Freud:

Vemos que o objeto está sendo tratado da mesma maneira que nosso próprio ego $^{2}$, de modo que, quando estamos amando, uma quantidade considerável de libido narcisista transborda para o objeto. [...] o ego se torna cada vez mais despretensioso e modesto e o objeto cada vez mais sublime e precioso, até obter finalmente a posse de todo o autoamor do ego [...]. O objeto, por assim dizer, consumiu o ego. (FREUD, [1921]1996, vol. XVIII, p. 122-123)

Todo o movimento feito por aquele que ama está, em última análise, em colocar o objeto amado no lugar do ideal do Eu. Diferentemente da identificação, na qual o Eu se molda conforme o objeto de amor e o introjeta, porque o mesmo foi perdido, o enamoramento indica um movimento do Eu para uma hipercatexia do objeto, sem que este tenha sido abandonado, ou perdido.

Apesar de todo esvaziamento libidinal que

2 Para a instância psíquica chamada por Freud de Ich, utilizamos, nesta dissertação, a tradução de $E u$. Porém, nos textos da edição de 1996 das Obras completas de Sigmund Freud, da editora Imago, a palavra utilizada na tradução do mesmo vocábulo em alemão é Ego. Achamos por bem, manter a tradução de 1996 da Imago, quando utilizarmos citações da mesma. acontece no Eu quando há um apaixonamento, Freud ensina, em 1914, que testemunhamos o narcisismo na vida amorosa dos seres humanos e também em outros dois momentos específicos: a observação da reação de uma pessoa à doença orgânica e a observação dos mecanismos de investimento libidinal na hipocondria.

Na observação da doença orgânica, é notório que a pessoa que se vê atormentada por um sofrimento e dor orgânicos deixa de se interessar pelas coisas do mundo que não dizem respeito ao seu sofrimento. A libido e o interesse do Eu [Ichinteresse] tem o mesmo destino e são indiferenciáveis entre si. Na hipocondria, o processo é o mesmo, apesar de não ser uma afecção orgânica. A explicação reside no princípio de erogeneidade do corpo, desenvolvida por Freud desde os Três ensaios. Ele explica que:

[...] certas outras localizações do corpo - as zonas erógenas - podem substituir os órgãos genitais e comportar-se de maneira análoga a eles. [...] poderemos considerar que a erogeneidade é uma faculdade geral de todos os órgãos e, portanto, nos referir a um aumento ou redução da erogeneidade em determinada parte do corpo. Em paralelo a cada uma dessas alterações da erogeneidade nos órgãos, poderia então estar ocorrendo uma alteração do investimento da libido no Eu. (FREUD, [1914]2004, vol. I, p. 105)

Estes fatores produziriam o mesmo efeito sobre a distribuição da libido se houvesse um adoecimento dos órgãos.

$\mathrm{O}$ represamento de libido no Eu é sentido como desprazeroso porque o desprazer é causado por uma maior tensão no aparelho psíquico. Saimos da fronteira do narcisismo e investimos libido nos objetos porque "essa necessidade entrará em cena quando o investimento de libido no Eu ultrapassar determinada quantidade." (FREUD, 2004, vol. I, p. 105)

Outra via de acesso ao estudo do narcisismo está na vida amorosa dos seres humanos. Existem dois tipos de escolha de objeto: aquela que é feita com base nas primeiras satisfações sexuais autoeróticas, atreladas às funções vitais de autoconservação, que elegem as pessoas envolvidas com o cuidado da criança, como objetos e é chamada de escolha por veiculação sustentada [Anlehnungs]; e aquela cujo objeto de amor não é pautado no cuidador da criança, mas na sua própria pessoa, ou seja, procura a si mesma como objeto de amor; esse tipo de escolha é chamado narcísico.

Ambas as escolhas de objeto estão franqueadas a todos os seres humanos, sendo que um ou outro caminho será privilegiado. Há, portanto, um narcisismo primário em cada ser humano, que pode manifestar-se, ou não, de maneira dominante em sua escolha de objeto.

Já para a mulher,

[...] especialmente nos casos em que [...] venha a crescer bela, produzir-se-á uma auto-suficiência que a compensará pela atrofia de sua liberdade de escolha do objeto, imposta 
pela sociedade. Em rigor, é só a si mesmas que essas mulheres amam com intensidade comparável à do homem que as ama. Elas não têm necessidade de amar, mas de ser amadas, e estão dispostas a aceitar o homem que preencher essa condição. (FREUD, [1916]2004, vol. I, p. 108)

Contudo, existem caminhos que levam a mulher ao amor objetal. Um deles é a maternidade, onde a criança será considerada parte de si mesma na forma de outro objeto. O outro é almejar nostalgicamente um ideal masculino que um dia a própria mulher já conhecera $\mathrm{e}$ tivera, antes da puberdade. Ela amaria o que fora e o que gostaria de ser, novamente.

O narcisismo, portanto, seria um dado essencialmente feminino. Uma vez que a pulsão não se veicula sobre o objeto, mas sobre o Eu, Freud concebe este movimento como eminentemente passivo. O mesmo raciocínio se aplica ao masoquismo, trabalhado no texto sobre as pulsões e seus destinos. O masoquismo é considerado uma transformação de uma finalidade pulsional ativa para uma passiva e, logo, feminina.

Contribuindo para a teoria acerca do masoquismo, em 1919 Freud escreve 'Uma criança é espancada': Uma contribuição ao estudo da origem das perversões sexuais. Na tentativa de elucidar um pouco mais, dentro da questão do complexo de Édipo, a gênese das perversões, ele descreve em três momentos o desenrolar da fantasia de espancamento presente em muitos atendimentos. Neste artigo, a ênfase é colocada na gênese da fantasia em casos contados por mulheres.

No que diz respeito à menina que fantasia o espancamento, há uma fixação amorosa ao pai, seguida de culpa. A menina partiria de um posicionamento de asseguramento de amor do pai, no ato do espancamento de outra criança. Mas pela culpa, esta fantasia se transforma em fantasia masoquista. Nas palavras de Freud:

A fantasia do período de amor incestuoso havia dito 'Ele (o meu pai) só ama a mim, e não à outra criança, pois está batendo nela.' O sentimento de culpa não pode descobrir um castigo mais severo do que a inversão desse triunfo: 'Não, ele não ama você, pois está batendo em você.' Desse modo, a fantasia da segunda fase, a de ser espancada pelo pai, é uma expressão direta do sentimento de culpa da menina, ao qual o seu amor pelo pai sucumbiu agora. A fantasia, portanto, tornou-se masoquista. (...) um sentimento de culpa é invariavelmente o fator que converte o sadismo em masoquismo. (FREUD, [1919]1990, vol. XVII, p. 204)

Para se afastar do amor incestuoso pelo pai, a menina deve abandonar o papel feminino e lançar mão de um "complexo de masculinidade", desejando ser menino. A saida é a identificação fálica, ativa, masculina. Quando há o recalque edípico, passa-se de uma posição feminina e masoquista para uma masculina e sádica. Feminino e masculino ainda coincidem com passividade e atividade. O que é da categoria da sexualidade feminina ou é considerado próximo da perversão masoquista ou não é nomeado como alternativa para a menina que se encontra ainda, nesse momento do ensino freudiano, subordinada à primazia fálica.

É interessante observar que é na mesma época de seu ensino que Freud escreve o artigo $O$ Tabu da virgindade (1918), no qual encontramos as seguintes palavras,

(...) que a mulher inteira é um tabu. A mulher não é unicamente tabu em situações especiais decorrentes de sua vida sexual, tais como a menstruação, a gravidez, o parto e o puerpério; além dessas situações, as relações sexuais com as mulheres estão sujeitas a restrições tão solenes e numerosas, que temos muitas razões para duvidar da suposta liberdade sexual dos selvagens. (FREUD, [1918]1996, p. 205)

Freud inicia o artigo propondo-se a investigar os motivos que levam algumas civilizações primitivas a estabelecer um tabu sobre a primeira relação sexual de uma mulher. Justifica o interesse pelo fato, o estabelecido de ser na perda da virgindade que a mulher pode derrotar as barreiras morais exigidas pela sociedade contra seus impulsos sexuais. É o primeiro momento em que essas resistências são vencidas. Também cita o termo cunhado por Krafft-Ebing "sujeição sexual", maneira em que a mulher se posiciona em relação ao homem que fora seu primeiro parceiro sexual. Esta sujeição tem consequências que convocam processos enraizados na inveja do pênis e no complexo de Édipo: um sentimento de amargura com relação a essa sujeição sexual.

Para investigar o tabu da virgindade, Freud lança mão de estudos sobre os costumes e tabus dos povos primitivos. Descreve que, curiosamente, em muitos povos primitivos, os rituais de matrimônio tinham como condição a abstinência do marido na primeira relação sexual com a noiva. A primeira relação poderia ser feita com o chefe da tribo, com o pai da noiva ou até mesmo com uma anciã.

Baseando-se em antropólogos contemporâneos a sua época, Freud enumera algumas razões para haver o tabu da virgindade nos povos primitivos. A primeira é o tabu do sangue: "Quando uma virgem é deflorada, de maneira geral, sangra: a primeira tentativa de explicação baseia-se, pois, no horror ao sangue entre as raças primitivas que consideram o sangue como a origem da vida." (FREUD, [1918]1998, vol. XI, p. 204) A presença do sangue seria assustadora e faria o marido se abster de deflorar sua noiva.

A segunda razão remeteria ao medo que o homem primitivo teria frente a uma experiência com o desconhecido, muito semelhante àquele presente na neurose de angústia. A terceira e última razão se fundamentaria na indicação de que o tabu da virgindade faria parte de uma soma de tabus que estariam postos em relação ao ato sexual.

Freud esbarra com mais dados acerca da sexualidade dos povos primitivos. Nestas civilizações 
há uma divisão entre os sexos:

As mulheres vivem com mulheres, os homens, com homens; a vida em família, como a entendemos, parece quase não existir em muitas tribos primitivas. Esta separação vai, às vezes, tão longe que não se permite a um sexo pronunciar em voz alta os nomes próprios dos membros do outro sexo e as mulheres criam uma linguagem com um vocabulário especial. (FREUD, [1918]1996, vol. XIX p. 205-206)

Partindo do raciocínio que o homem primitivo institui um tabu quando teme algum perigo, é interessante a observação de que os homens parecem querer se afastar das mulheres, nas tribos primitivas. Ficam separados, juntos com outros homens, exatamente porque temem ser enfraquecidos pelas mulheres, como se elas pudessem contaminá-los. "O homem teme ser enfraquecido pela mulher, contaminado por sua feminilidade" (FREUD, [1918]1996, vol. XIX p. 206). Interessante constatarmos no texto freudiano esse medo que se põe à mulher, que carregaria qualquer coisa que causa temor ao homem, algo incógnito que ele denomina de "feminilidade". Freud recorre à castração como explicação para a hostilidade e o medo dessa contaminação que a feminilidade poderia produzir; castração que a mulher traz no seu próprio corpo. Esta representação levaria à hostilidade e ao receio tanto do homem primitivo quanto no homem civilizado.

Mesmo que Freud (1918) aponte somente a ameaça de castração como causa para o horror ao que é feminino, o que ele acaba por indicar nesse artigo é que tanto o homem quanto a mulher ressentem esse encontro com a feminilidade, que seria de fato assustador, mas não exatamente pela falta do órgão que lhe teria sido tirado, mas pela experiência de um encontro com a dor e a morte, já indicada por Freud na questão da virgindade, da menstruação e do sangue.

Parece que Freud se aproxima da questão da falta do órgão e da castração por outra via que não a fálica, quando indica que qualquer argumentação não esgota, muito menos explica, o tabu da virgindade. A castração seria um testemunho do que é caracteristicamente feminino.

Sendo a virgindade o tema em questão, Freud (1918) investiga também os fenômenos que ocorrem com relação à primeira relação sexual das mulheres civilizadas. Ele postula que o primeiro ato sexual ativaria na mulher pulsões antigas, que estariam em absoluta oposição à posição passiva feminina. Desta forma, recorre aos arranjos do complexo de masculinidade, que fora destituído com a entrada no complexo de Édipo. Mais uma vez, é a castração, pelo caminho da inveja do pênis, que vem responder o que é eminentemente feminino.

Já que a feminilidade estaria conectada diretamente com a inveja do pênis, Freud faz menção ao desejo da mulher de ter um filho, em substituição ao desejo de ter pênis. Para ele, essa é a única saída possível para um desejo propriamente feminino.

Os lineamentos teóricos de 1918 acerca da sexualidade feminina não puderam designar uma sexualidade puramente feminina, já que a mesma estaria toda submetida ao movimento masculino fálico. Ao mesmo tempo em que, ao escrever o Tabu da virgindade Freud pôde tocar na noção da mulher como tabu e enigma, remetendo-nos à falta de um representante que a feminilidade e o corpo feminino encarnam, ele permanece fiel à primazia fálica, quando estabelece toda a teoria da sexualidade feminina sempre subordinada à questão fálica. Com a primazia do falo como representante sexual, Freud se afasta de perceber que a polaridade presença/ausência do falo indica também um campo fora do registro simbólico, e que este campo é representado pelo feminino. Freud irá apostar até o fim do seu ensino na questão fálica e no Complexo de Édipo.

Porém, uma diferença teórica se presentifica quando Freud se depara com a história pré-edipiana da menina. É a partir do segundo tópico freudiana e da concepção da pulsão de morte, em 1920, que toda a abordagem acerca da sexualidade infantil e do feminino é revista, assim como outros pontos importantes da doutrina psicanalítica. Somente após este caminho percorrido, Freud poderá debruçar-se em uma teoria sobre a sexualidade feminina e a feminilidade.

\section{0: Além do princípio do prazer e suas consequências teóricas}

Com a reformulação que Freud faz de suas teorias mais importantes a partir de 1920 e do texto Além do princípio do prazer (1920), o dualismo pulsional, antes teorizado como pulsão sexual e pulsão do Eu, é modificado pelos polos pulsão de vida e pulsão de morte. Para o desenvolvimento desta evolução teórica, Freud observa a compulsão à repetição presente na neurose traumática, na transferência e em algumas brincadeiras infantis.

No texto supracitado, Freud começa por argumentar que o princípio geral que orienta a ação das pessoas é o princípio do prazer, definido como uma produção de sensações prazerosas ou de estratégias de escapatória do desprazer. Entretanto, sob a influência de impulsos de auto-preservação do eu, o princípio do prazer geralmente sofre algumas modificações e assume a forma do princípio de realidade, o que geralmente “(...) exige e efetua o adiamento da satisfação, o abandono de uma série de possibilidades de obtê-la, e a tolerância temporária do desprazer como uma etapa no longo e indireto caminho para o prazer." (FREUD, [1920]1996, vol. XVIII, p. 20).

O princípio de realidade, essencialmente, 
funciona sob a mesma lógica com o princípio do prazer, porque o adiamento do prazer é incitado pelos impulsos de auto-preservação, na tentativa de evitar a morte e a autodestruição.

No entanto, o princípio do prazer não pode explicar alguns comportamentos humanos específicos, como os constantes nas neuroses traumáticas e na conduta masoquista, por exemplo. Para tanto, Freud propõe um princípio fundamental que substitui o princípio do prazer: a compulsão à repetição. Um exemplo desse tipo é encontrado no caso de neuroses traumáticas em que o paciente está fixado nos traumas psíquicos da infância e, repetidamente, volta a esta cena traumática em seus sonhos. Essa revisitação constante da cena traumática de forma alguma produz qualquer prazer, não conduz a qualquer experiência agradável.

A compulsão à repetição parece ser a única explicação para esse tipo de tortura. Freud, em seguida, postula que todos os impulsos orgânicos são essencialmente uma compulsão para retornar a um estado primitivo das coisas. Apesar das condições externas interferirem para modificar a rota do caminho de retorno de um organismo, elas não podem mudar seu destino final. Estas interferências externas, todavia, não acontecem em vão. Freud ensina que qualquer modificação imposta ao longo da vida do organismo é aceito pelos impulsos orgânicos conservadores e armazenada para a repetição. Esta interferência externa constante complica o círculo da repetição e constitui o espaço para a singularidade que, ainda assim, não pode escapar do círculo final da repetição.

Dentre todos os impulsos vindos da repetição, o mais primitivo é o retorno ao inanimado. Tendo em conta que objetos inanimados existiram antes dos seres vivos, Freud chega à conclusão de que o primeiro impulso seria retornar ao estado inanimado. Com base nisso, Freud problematiza o par de pulsões ${ }^{3}$ de oposição, que se levantou em seus primeiros trabalhos: pulsões do ego contra as pulsões sexuais. Em vez disso, ele propôs uma nova díade de termos. A vida, então, seria um desvio da morte e a contrapartida fiel à pulsão de morte seria o a pulsão de vida, ou Eros. O importante desta distinção é que Freud nos mostra que a pulsão de vida está ligada ao que é da ordem do sexual e, portanto, funciona sob a lei fálica. A pulsão de morte seria o contrapeso desta lei.

Com isso podemos inferir que, se na vida psíquica não existe somente o que é referido ao campo sexual, se não temos somente o registro fálico que nos divide entre castrados e não-castrados, se há algo que excede o que está nessa partilha, é porque há algo referido à pulsão de morte e que não aceita delimitação. Lacan, mais tarde, indicaria o feminino como esse outro campo. Para elucidar a especificidade do feminino, é preciso levar

3 Preferimos utilizar a tradução pulsão e não instinto para a palavra alemã Trieb. em conta um mais além do falo. O feminino, portanto, assinalaria algo da pulsão de morte e não algo da pulsão sexual. Esse raciocínio teórico será desenvolvido nos capítulos seguintes.

O masoquismo foi outro tema ligado ao feminino que também mereceu uma reformulação a partir da noção de pulsão de morte. Em 1924, Freud escreve $O$ Problema econômico do masoquismo.

Até 1920 não era possível pensar na existência de um masoquismo estrutural, pois se os processos mentais são regidos pelo princípio do prazer, o masoquismo fica como enigma incompreensível. Para o entendimento do mecanismo do masoquismo deve-se, portanto, investigar a conexão do princípio do prazer com as pulsões de vida e de morte. Nas palavras de Freud;

Todo desprazer deve assim coincidir com uma elevação e todo prazer com um rebaixamento da tensão mental devida ao estímulo; o princípio de Nirvana (e o princípio de prazer, que lhe é supostamente idêntico) estaria inteiramente a serviço dos instintos de morte, cujo objetivo é conduzir a inquietação da vida para a estabilidade do estado inorgânico, e teria a função de fornecer advertências contra as exigências dos instintos de vida - a libido - que tentam perturbar o curso pretendido da vida. (FREUD, [1924]1996, vol. XIX, p. 177-178)

O masoquismo é considerado como tributário da pulsão de morte, pois é resto da operação que a libido realiza ao expulsar parte da pulsão destrutiva para fora do psiquismo, sob forma de sadismo. O masoquismo é, portanto, original e estrutural. Por ser resto de uma operação ativa, também é associado à passividade e qualquer atitude passiva em relação à vida sexual é ligada ao masoquismo. O termo feminino - que, como vimos, está sempre associado à passividade - aparece neste texto como uma das formas que o masoquismo se apresenta, a saber: i) como condição imposta à excitação sexual, masoquismo erógeno; ii) como expressão da natureza feminina, masoquismo feminino; e iii) como forma de comportamento, masoquismo moral.

Sobre o masoquismo feminino, Freud afirma que é o mais acessível à observação e pode ser examinado em todas as relações. Relaciona-se a uma posição passiva com relação ao ato sexual ou à fantasia erótica. Além de remeterem ao desejo do homem de ser tratado como uma criança travessa e punido, também remetem ao desejo de ser castrado ou de ter um filho. Condições mais do que sabidas pela teoria psicanalítica como femininas: castração e maternidade. Sobre as fantasias masoquistas, Freud afirma:

[...] de imediato se descobre que elas colocam o indivíduo numa situação caracteristicamente feminina; elas significam, assim, ser castrado, ou ser copulado, ou dar à luz um bebê. Por essa razão chamei essa forma de masoquismo [...] de forma feminina, embora tantas de suas características apontem para a vida infantil. (FREUD, 1996, vol. XIX, p. 180)

O masoquismo feminino baseia-se, então, 
no masoquismo primário e erógeno, precisamente descrito nos Três ensaios, em 1905. No entanto, sem o entendimento da pulsão de morte e da compulsão à repetição, não haveria como compreender a que serve um movimento pulsional como este. Ao impelir o sujeito a repetir aquilo que causa angústia, como a submissão e a castração que ela serve de alegoria, pode representar por fantasias e ações aquilo que é próprio da feminilidade e, logo, fora da rede representacional fálica do sujeito. Não é coincidência que a palavra feminilidade apareça muito mais vezes depois de 1920, após a fundamentação da pulsão de morte. A feminilidade é posta no mesmo estatuto destes dois grandes conceitos: fora da lógica fálica.

\section{A teorização freudiana final acerca da sexualidade feminina e da feminilidade}

A partir da reformulação trazida com a teoria da pulsão de morte, da compulsão à repetição, Freud também reformula toda sua teoria da sexualidade feminina e deixa de lado a proposição anterior de simetria com a sexualidade masculina. Ele começa a investigar os meandros e singularidades da sexualidade feminina, sua relação com o complexo de Édipo e o desenrolar da feminilidade. No período de 1919 até 1933, a teoria da sexualidade feminina amadurece e ganha seus últimos arremates.

O percurso que Freud atravessa para a modificação da concepção da sexualidade feminina aparece em textos sobre a teoria da castração e sua relação com o complexo de Édipo. O primeiro deles é A Organização genital infantil: uma interpolação na teoria da sexualidade, de 1923. Este artigo é, como indica o título, um adendo aos Três ensaios, principalmente das seções 5 e 6 do segundo ensaio, seções que dizem respeito à investigação sexual infantil e ao desenvolvimento da sexualidade infantil. Sua grande contribuição está na sedimentação do conceito de falo e da teoria do complexo de Castração. Ele revê a tese de 1908, que dizia que, nas teorias sexuais infantis só havia um sexo, o pênis, e que este seria sempre presente, tanto no menino quanto na menina, que teria o seu muito pequeno ou em vias de desenvolvimento. Em 1923, Freud afirma que o menino reconhece a falta de pênis na menina e finalmente localiza na falta o poder da castração e o pênis pode ser significantizado como falo por comparecer em falta em outro corpo.

Esobre a castração, Freud afirma:“(...) o significado do complexo de castração só pode ser corretamente apreciado se sua origem na fase da primazia fálica for também levada em consideração." (FREUD, [1923]1996, vol. XIX, p. 159-160) O falo é levado em consideração como o único órgão sexual, manifestandose por sua presença e ausência. Nas palavras de André:

Em outras palavras, não há senão um sexo, o falo, mas há

4 Grifos do próprio autor. dois modos de manifestação: ou a presença, ou a ausência. O que significa que a falta do pênis, se reconhecida, é enquanto falo (a menos) e não enquanto sexo feminino. [...] A castração faz da ausência um resto de presença, ela é um embelezamento [...] ou, melhor ainda, um eufemismo (sentido figurado). (ANDRÉ, 1998, p. 12-13)

Ainda não há avanço sobre o caminho que as meninas percorrem neste processo. Freud somente descreve o Complexo de Castração pela ótica do menino. “(...) os processos correspondentes na menina não conhecemos" (FREUD, [1923]1996, vol. XIX, p. 158), ele diz. O Complexo de Castração nas meninas e seus desdobramentos edípicos começam a tomar corpo a partir de 1924 com o artigo $A$ dissolução do complexo de Édipo, onde há, pela primeira vez, a ênfase ao caminho diferente que meninos e meninas tomam no desenvolvimento de sua sexualidade.

É neste trabalho que Freud se ocupará com a hipótese que a destruição do complexo de Édipo é ocasionada pela ameaça de castração. Uma vez que as meninas, pela sua natureza anatômica, são castradas, o caminho para a dissolução do Édipo feminino deve ser outro.

No menino, é a ameaça de castração que ocasiona o desmoronamento da organização genital fálica. No entanto, esta ameaça só produz efeito a posteriori, quando o menino se depara com a visão dos órgãos genitais femininos. "Com isso, a perda de seu próprio pênis fica imaginável e a ameaça de castração ganha seu efeito adiado." (FREUD, [1924]1996, vol. XIX, p. 195).

Uma vez que a consequência para que a fantasia do complexo de Édipo se realize é a castração, o menino se vê num embate entre seu interesse narcísico e a catexia libidinal investida em seus objetos parentais. Neste conflito vence o narcisismo e o menino deixa seus impulsos edipianos de lado.

Esta desistência, no entanto, tem conseqüências. As catexias são substituídas por identificações. Freud explica que:

\footnotetext{
A autoridade do pai ou dos pais é introjetada no ego e aí forma o núcleo do superego, que assume a severidade do pai e perpetua a proibição deste contra o incesto, defendendo assim o ego do retorno da catexia libidinal. As tendências libidinais pertencentes ao complexo de Édipo são em parte dessexualizadas e sublimadas (coisa que provavelmente acontece com toda transformação em uma identificação) e em parte são inibidas em seu objetivo e transformadas em impulsos de afeição. (FREUD, [1924]1996, vol. XIX, p. 196)
}

No que diz respeito ao processo nas meninas, Freud instrui que o clitóris seria um equivalente do pênis, mas não seria um representante fálico por muito tempo. A fantasia feminina vai da crença de que o clitóris crescerá e será um apêndice tão grande quanto o do menino até o deslizar metonímico (ou, nos termos de Freud, a equação simbólica) do pênis para um 
bebê. O complexo de Édipo feminino tem seu ápice no desejo de receber do pai um filho como presente. Uma vez que este desejo jamais se realiza, o complexo de Édipo é abandonado e o anseio permanece catexizado no inconsciente, preparando a menina para o papel posterior de mãe.

Mas este argumento não é suficiente para explicar fenômenos edipianos com os quais Freud se depara em sua clínica. Ainda em 1920, ele havia se debruçado na descrição e análise de um caso de uma jovem de dezoito anos, enamorada por uma dama mais velha. $\mathrm{O}$ caso ficará conhecido na literatura psicanalítica como " $O$ caso da jovem homossexual". No estudo deste caso, a questão que se abre é de saber se a relação que a jovem tem com seu pai, instaurada a partir de seu complexo de Édipo, é um deslocamento da relação, muito mais primitiva e estruturante, mantida com a mãe. Freud volta sua atenção à pré-história do complexo de Édipo no desenvolvimento libidinal e reestrutura sua teoria.

Da tentativa de responder sobre a fase préedipiana e de responder definitivamente sobre o processo do complexo de Édipo e suas conseqüências, surge o texto Algumas Conseqüências Psíquicas da Distinção Anatômica entre os Sexos (1925).

Neste texto de 1925, Freud repete o que afirmara em 1905: a mãe é o objeto de amor original para a criança de ambos os sexos. Como se dá, então, para a menina, a passagem do amor materno para o pai como objeto amoroso? O complexo de Édipo das meninas tem uma longa pré-história e, de certa forma, é uma formação secundária. Nas palavras de Freud:

Nas meninas, o complexo de Édipo é uma formação secundária. As operações do complexo de castração o precedem e preparam. [...] Enquanto nos meninos, o complexo deÉdipoédestruído pelo complexo de castração, nas meninas ele se faz possivel e é introduzido através do complexo de castraçãos. (FREUD, [1925]1996, vol. XIX, p. 285)

O menino faria sua entrada no complexo de Édipo pelo amor que sente pela mãe e o pai compareceria no romance familiar como rival e agente impossibilitador deste amor. A saída do Édipo, portanto, remete ao complexo de castração.

Com a menina a história é mais complexa. Ela teria que abrir mão da primeira relação de amor objetal que tem com a mãe, ligação que influencia suas outras escolhas objetais e seu desenvolvimento libidinal futuro. Abre mão ao se dar conta de que sua mãe também é castrada, desenvolvendo, então, a hostilidade para com a mãe necessária para que a menina volte-se para o pai e o eleja como objeto amoroso, por ter aquilo que nem ela e nem a mãe tem. Com isso fica claro que é a partir das tramas pré-edipianas que a entrada no complexo de castração conduz ao complexo de Édipo feminino.

Sobre o período chamado pré-edipiano, Freud

5 Grifo do próprio autor. faz grandes considerações teóricas em 1931, no artigo Sexualidade Feminina. Ele retoma a argumentação já apresentada em 1925 de que, na menina, o primeiro objeto de amor também é a mãe, assim como no menino. No entanto, Freud se pergunta como a menina encontra caminho para o pai e como se desliga da mãe. A sexualidade feminina já é uma empreitada complicada se pensamos na tarefa que a menina deve exercer de abandonar sua principal zona genital, que é o clitóris originalmente, em favor da vagina. Complica-se mais ainda se pensamos que, além da troca de zonas genitais, a menina também deve trocar de objeto: deve trocar a mãe, primeiro objeto de amor, pelo pai. Esta troca é fundamental para o desenvolvimento da chamada feminilidade normal.

A relação da menina com o pai é herdeira da ligação materna. $\mathrm{O}$ texto informa que quanto mais apaixonada é a ligação de uma menina com seu pai, mais exclusiva teria sido sua relação com a mãe, ao ponto de a relação de exclusividade permanecer a mesma e só haver, efetivamente, mudança de objeto. A duração dessa ligação entre mãe e menina também é um fator a ser considerado. Freud diz:

Na verdade, tínhamos de levar em conta a possibilidade
de certo número de mulheres permanecerem detidas
em sua ligação original com a mãe e nunca alcançarem
uma verdadeira mudança em direção aos homens.
Assim sendo, a fase pré-edipiana nas mulheres obtém
uma importância que até agora não lhe havíamos
atribuído. (FREUD, [1931]1996, vol. XXI, p. 234)

Ele aponta, então, que é no vínculo entre mãe e filha, sedimentado na fase pré-edipiana, que estão todas as fixações e repressões a que podemos remontar a origem da neurose e a etiologia da histeria.

Nas mulheres, a vida sexual é dividida em duas fases, uma de caráter masculino e que tem como zona erógena o clitóris e outra que é especificamente feminina e tem como zona erógena a vagina. O clitóris e o seu caráter viril, no entanto, continua funcionando na vida sexual feminina como um todo. Freud diz, ainda, que a mudança no sexo da mulher deve corresponder à mudança de sexo do seu objeto de amor. Afirma também que a maneira pela qual esta mudança ocorre: se é radical ou incompletamente efetuada e as diferentes possibilidades que se apresentam neste decurso são problemas que exigirão investigação.

São três os efeitos do complexo de castração na mulher. O primeiro seria um asco geral à sexualidade. A menina cresceria insatisfeita com seu clitóris, assustada pela comparação com os meninos. Abandonaria, então, sua atividade fálica, sua sexualidade em geral e boa parte de sua masculinidade em outros campos.

$\mathrm{O}$ segundo efeito seria a auto-afirmatividade à masculinidade ameaçada. A menina aferrar-se-ia, até uma idade tardia, à esperança de conseguir um 
pênis. Novamente Freud lança mão do complexo de masculinidade, com a diferença de que agora poderia levar a uma escolha homossexual de objeto. O terceiro e último efeito seria a atitude feminina considerada normal, que leva a menina a tomar o pai como objeto e à entrada para a forma feminina do complexo de Édipo. Retomando a teoria de 1925, o Édipo, então, advém pela influência da castração, no caso das mulheres.

Existem alguns fatores operando juntos para o afastamento da menina de sua mãe. Freud cita:

[...] que ela [a mãe] falhou em fornecer à menina o órgão genital correto, que não a amamentou o suficiente, que a compeliu a partilhar o amor da mãe com outros, que nunca atendeu às expectativas de amor da menina e, finalmente, que primeiro despertou a sua atividade sexual e depois a proibiu [...] (FREUD, [1931]1996, vol. XXI, p. 242)

O primeiro deles, o ressentimento que a menina tem de sua mãe por tê-la trazido ao mundo como mulher, já fora rascunhado por Freud em contextos anteriores, como em 1925. A constatação de sua própria castração e a de sua mãe tem como consequência narcísica a inveja do pênis. Novamente verificamos que a questão fálica é proposta como alavanca que direciona a menina a estabelecer o caminho para a feminilidade. Portanto a construção da feminilidade estaria totalmente submetida à ferida narcísica e à Penisneid, consequentemente.

A menina acusa a mãe de tê-la feito como ela, incompleta. Mas essa acusação nos aponta uma identificação já estabelecida com a mãe, pela via da similaridade dos corpos. Assim, essa identificação torna-se profundamente ambivalente, uma vez que, com a descoberta da castração, a menina descobre que, além dela, sua mãe também é castrada. Nas palavras de Freud

“[...] ao final dessa primeira fase de ligação com a mãe, emerge, como motivo mais forte para a menina se afastar dela, a censura por a mãe não the ter dado um pênis apropriado, isto é, tê-la trazido ao mundo como mulher.” (FREUD, [1931]1996, vol. XXI, p. 241-242)

Conhecemos a assertiva derradeira de Freud (1932), segundo a qual a relação mãe-filha, pela intensidade da libido aí presente e por sua longa duração, quase parece predestinada a terminar em ódio. Se não em ódio dirigido à própria mãe, pelo menos em ódio dirigido ao parceiro masculino que herda 0 mesmo vínculo. Na Conferência XXXIII, cujo título é Feminilidade (1932), Freud ratifica que a mãe é sempre considerada provida de falo, tanto pelos meninos, como pelas meninas; que nada justifica clinicamente a justaposição "libido feminina"; e que o necessário falicismo da menina eclipsa a diferença entre os sexos.

Neste texto, mais especificamente, Freud reconhece e reafirma a feminilidade como enigma para a teoria psicanalítica. Também reconhece toda a sexualidade humana como enigmática, pois a anatomia não pode responder pela feminilidade e nem pela masculinidade. Da mesma forma que seria um erro entender a noção de bissexualidade a partir da dicotomia atividade/passividade. Portanto entender a feminilidade pela via da passividade não esclarece os elementos da própria feminilidade. Nas palavras de Freud:

Até mesmo na esfera da vida sexual humana os senhores verão
logo como é inadequado fazer o comportamento masculino
coincidir com atividade e o feminino, compassividade. [...]As
mulheres podem demonstrar grande atividade, em diversos
sentidos; os homens não conseguem viver em companhia
dos de sua própria espécie, a menos que desenvolvam uma
grande adaptabilidade passiva. Se agora os senhores me
disserem que esses fatos provam que tanto os homens, como
as mulheres são bissexuais, no sentido psicológico, concluirei
que decidiram, na sua mente, a fazer coincidir "ativo" como
"masculino" e "passivo" com "feminino". Mas advirto-
os que não o façam. Parece-me que não serve a nenhum
propósito útil e nada acrescenta aos nossos conhecimentos.
[...] Poder-se-ia considerar característica psicológica
da feminilidade dar preferência a fins passivos. Isto,
naturalmente, não é o mesmo que passividade, para chegar a
um fim passivo, pode ser necessária uma grande quantidade
de atividade (FREUD, [1933]1996, vol. XX, p. 116).

No que diz respeito à pulsão, afirma tratar-se de uma dicotomia inexistente. Além disso, do ponto de vista da posição feminina, a posição passiva só é alcançada mediante uma intensa atividade.

Uma vez que a passividade deixa de ser o significante que responde sobre a feminilidade, Freud fica sem nenhum significante para circunscrever a feminilidade, a não ser o significante enigma. E sobre o enigma, não há o que se possa dizer. Interessante pensarmos que Freud, ao tentar responder sobre a feminilidade com a saída edipiana da menina, repete miticamente a cena lendária de Édipo frente à esfinge. Ao ver-se convocado a responder ao enigma da esfinge que a sexualidade feminina encarna, Freud tenta, em vão, mimetizar a resposta de Édipo ${ }^{6}$ e articular toda sua teoria tangenciando-a a sexualidade masculina. Ele tenta, em vão, partir da teoria libidinal e a da passividade, tão útil durante o percurso da teorização sobre a sexualidade. Mas essa já não lhe serve mais, pois a feminilidade não é apenas passiva, há algo além deste significante.

Já que descrever o que é a mulher é enigmático e talvez impossível, Freud então propõe investigar o tornar-se mulher, ou seja, entender em que ponto a menina deixa sua sexualidade primitiva masculina e volta seus vetores libidinais para os interesses femininos. Sobre isto Freud desenvolve duas premissas básicas: "A primeira é que aqui, novamente, a constituição não se

6 "Édipo teria conseguido vencer a esfinge, respondendo que o animal aludido no enigma [...] era o homem que na infância (manhã da vida) usava as mãos e os pés para engatinhar; depois (meio-dia) usava os pés, e na velhice (tarde) tinha de recorrer a um bordão para poder caminhar." (SÓFOCLES, trad. Mário da Gama Kury, pág. 98, 2004) 
adaptará à sua função sem uma luta. A segunda reside em que os pontos decisivos já terão sido preparados ou completados antes da puberdade" (FREUD, [1933]1996, vol. XX, p. 117).

A feminilidade, então, não tem uma existência dada, mas construída. Isso indica que muitas mulheres podem atuar como homens e nunca se tornarem verdadeiramente mulheres. Tornar-se mulheré, portanto, um trabalho de elaboração que necessita de uma luta que vai contra a constituição psíquica e a lógica fálica, uma vez que a menina iniciaria seu desenvolvimento libidinal como um menino. Será só depois de abrir mão da masculinidade que a menina pode "vir-a-ser" mulher e ocupar uma posição verdadeiramente feminina.

A luta em direção à feminilidade culmina quando a menina abandona a relação pré-edipiana com a mãe e entra no complexo de Édipo. Este movimento só é possível se a menina abdicar de seu gozo clitoridiano e de sua posição ativa. No entanto, há um paradoxo: se a menina abandona a atividade, desiste também da busca pelo falo e a razão para voltar-se ao pai não existirá. Freud aponta, então, que se trata de assumir uma posição passiva, mas não totalmente passiva, para que a demanda fálica ainda possa operar e a menina possa se posicionar de acordo com a saída feminina que Freud teoriza.

Freud aponta, então, que a demanda fálica possível na posição feminina será, como já se disse, o desejo de ter um filho. Com isso, a condição propriamente feminina só se estabelece de fato, se o desejo de ter um pênis for substituído, como já se disse, pelo desejo de ter um filho.

O desejo que leva a menina a voltar-se para seu pai é, sem dúvida originalmente o desejo de possuir o pênis que a mãe lhe recusou e que agora espera obter do pai. No entanto, a situação feminina só se estabelece se o desejo do pênis for substituído pelo desejo de um bebê, isto é, se um bebê assume o lugar do pênis, consoante uma primitiva equivalência simbólica (FREUD, [1933]1996, vol. XXII, p. 128).

É importante observarmos que este desejo edipiano de ter um filho é diferente do que ocorre na fase pré-edipiana. A menina que brinca com a boneca se posiciona como a mãe, pela via de uma identificação com a posição ativa que a mãe pré-edipiana encarna. Paradoxalmente, é somente após desejar ter um pênis que a menina pode alcançar o desejo de ter um bebê e se construir mulher. Isso esclarece a posição freudiana que indica que a mulher só pode ser construída a partir da castração e do seu resultado mais direto: a inveja do pênis.

Para Freud, portanto, uma mulher só pode ser feminina se ela estiver direcionada ao falo e se seu desejo se configurar como desejo de ser mãe. A consequência dessa teoria é que Freud não consegue criar uma teoria designadamente feminina, nem apontar para uma especificidade própria da mulher no que diz respeito ao modo de satisfação pulsional.

Freud segue o raciocínio e afirma que no casamento uma relação pacífica entre homem e mulher só pode acontecer se a mulher atuar como mãe e o marido como filho. Se ambos se posicionarem de outro modo, a mulher não resiste à sua história pré-edipiana e pode fazer ressurgir a primeira relação com a mãe no seio de seu casamento. Portanto, a ligação amorosa entre homem e mulher só seria garantido pela identificação feminina com a mãe, que também possibilitaria o homem retornar ao seu complexo de Édipo e, reatualizando o antigo amor pela mãe, enamorar-se de sua mulher.

Finalmente, no artigo Análise terminável $e$ interminável de 1937, Freud alinhava suas últimas teorias acerca da feminilidade. O texto mostra que, por mais que a teoria sobre o feminino se desenvolvesse, esse significante sempre apontaria para um campo além da lógica fálica e, portanto, próxima da pulsão de morte. A feminilidade, então, teria um lugar semelhante à pulsão de destrutividade, à compulsão à repetição e todos os elementos psicanalíticos relacionados à pulsão de morte.

Neste texto, Freud repete a idéia de que há um trabalho que cada mulher deve realizar para construir sua "feminilidade". Cada mulher deve trilhar um caminho próprio nesta construção, que depende diretamente de como ela se posicionará diante da lógica fálica, a partir do processo de recalcamento da masculinidade. A feminilidade, neste momento da obra de Freud é colocada como parte do enigma que o sexo, como fenômeno psíquico, carrega. Sabe-se que o biológico de nada adianta para decifrar tal enigma e o que a castração indica é que há algo além de uma ausência. A questão da feminilidade excede a castração e a inveja do pênis, por apontar um campo que vai além de uma reivindicação fálica.

\section{Referências}

André, Serge. (1998) O que quer uma mulher? Jorge Zahar.

Freud, S. (1996) "Três ensaios sobre a teoria da sexualidade [1905]" In: Edição standard brasileira das obras psicológicas completas. v. VII. Rio de Janeiro: Imago, p. 119-231.

(1996) "Fantasias histéricas e sua relação com a bissexualidade [1908]" In: Edição standard brasileira das obras psicológicas completas. Rio de Janeiro: Imago, v. IX. p. 147-154.

(1996) "Análise de uma fobia em um menino de cinco anos [1909]" In: Edição standard brasileira das obras psicológicas completas. Rio de Janeiro: Imago, v. X. p. 13-133.

(2004). "À Guisa de introdução ao narcisismo [1914]” In: Escritos sobre a psicologia do inconsciente. Rio de Janeiro: Imago, V. I. p. 95-119.

(1996) "O Tabu da virgindade (Contribuições à Psicologia do Amor III)" [1918[1917]] In: Edição standard brasileira das obras psicológicas completas. Rio de Janeiro: Imago, v. XI, p. 199-215.

(1996) “Conferência XXI [1916-1917]” In: Edição standard brasileira das obras psicológicas completas. Rio de Janeiro: Imago, v. XVI. p. $325-342$. 
(1996) “Uma criança é espancada': Uma contribuição ao estudo da origem das perversões sexuais [1919]" In: Edição standard brasileira das obras psicológicas completas, Rio de Janeiro: Imago, v. XVII. p. 193-218.

. (2003) Além do princípio do prazer [1920], Rio de Janeiro: Imago.

(1996) "A Psicogênese de um caso de homossexualismo numa mulher [1920]" In: Edição standard brasileira das obras psicológicas completas. Rio de Janeiro: Imago, v. XVIII. p. 183-212.

. (1996) "Organização genital infantil: uma interpolação na teoria da sexualidade [1923]" In: Edição standard brasileira das obras psicológicas completas. Rio de Janeiro: Imago, v. XIX. p. 155-161.

. (1996) "O problema econômico do masoquismo [1924]" In: Edição standard brasileira das obras psicológicas completas. Rio de Janeiro: Imago, v. XIX. p. 175-188.

(1996) "A dissolução do complexo de Édipo [1924]" In: Edição

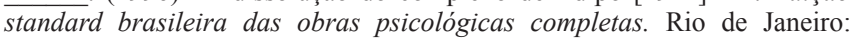
Imago, v. XIX. p. 191-199.

. (1996) "Algumas consequências psíquicas da distinção anatômica entre os sexos [1925]" In: Edição standard brasileira das obras psicológicas completas. Rio de Janeiro: Imago, p. 273-286.

(1996) "Sexualidade feminina [1932]" Edição standard brasileira das obras psicológicas completas. Rio de Janeiro: Imago, v. XXI. p. $257-$ 282.

(1996) "Feminilidade [1933]" In: Edição standard brasileira das obras psicológicas completas. Rio de Janeiro: Imago, v. XXII. p. 157-172.

(1996) "Análise terminável e interminável [1937]" Edição standard brasileira das obras psicológicas completas. v. XXIII. Rio de Janeiro: Imago, p. 225-270

Sófocles. (2005). Édipo Rei, DIFEL, 3ª Ed. 